Vol. 6, No. 1, Oktober 2021

\title{
IMPLEMENTASI METODE FIFO DALAM PERHITUNGAN NILAI PERSEDIAAN PADA PT.X DISTRIBUTOR MAKANAN DI JAWATIMUR
}

\author{
ANNISA RAHMAWATI ${ }^{1}$ \\ Universitas 45 Surabaya \\ rahmawaty.annisa@gmail.com

\begin{abstract}
ACHMAD DAENGS GS 2
Universitas 45 Surabaya

bumigora80@gmail.com
\end{abstract}

\section{Article History:}

Received: 15 Maret 2021

Revised: 31 Juli 2021

Accepted: 14 Agustus 2021

DOI: $10.29303 / j a a . v 6 i 1.103$
Abstract: The valuation of the inventory value has an important role in several financial statements (balance sheet and the income statement). Misrepresentation of inventory values can result in exposure to financial statements that do not reflect the actual economic condition of the company. PSAK No. 14 explains that except for companies that have inventories that are specially produced and cannot be replaced, these inventories are usually valued using the First In First Out method. PT $X$ is a snack food distributor company in East Java that conducts inventory assessment using the Last In First Out method, which is not in accordance with the explanation of PSAK No. 14. This research was conducted with a case study approach. This study aims to describe the phenomenon of the implementation of the inventory valuation method with the Last In First Out valuation method on PT.X. The results of this study, explains the implementation of the First In First Out valuation method can provide a more reasonable exposure to inventory valuation because in companies with inventories that are classified as perishable such as PT X, The First In First Out method can provide an inventory assessment that is in accordance with the movement of goods. 
Abstrak: Penilaian terhadap nilai persediaan memiliki peranan penting dalam dua laporan keuangan sekaligus, yakni dalam pemaparan neraca dan pemaparan laporan laba rugi. Kesalahan dalam penyajian nilai persediaan dapat mengakibatkan paparan laporan keuangan tidak mencerminkan kondisi ekonomi perusahaan yang sesungguhnya. Metode penilaian persediaan terbagi menjadi tiga yakni First In First Out, Last in First Out dan Average. PSAK No 14 memaparkan bahwa kecuali pada perusahaan yang memiliki persediaan yang di produksi secara khusus dan tidak dapat digantikan, maka persediaan tersebut lazimnya di nilai dengan metode First In First Out. PT X merupakan perusahaan distributor makanan ringan di Jawa Timur yang menyelenggarakan penilaian persediaannya dengan menggunakan metode Last In First Out, dimana hal ini tidak sesuai dengan paparan PSAK No. 14. Penelitian ini dilakukan dengan pendekatan studi kasus. Penelitian ini bertujuan untuk memaparkan fenomena kasus pelaksanaan metode penilaian persediaan dengan metode penilaian Last In First Outpada laporan keuangan PTX. Hasil dari penelitian ini memaparkan bahwa implementasi metode penilaian First In First Out dapat memberikan paparan penilaian persediaan yang lebih wajar karena pada perusahaan dengan persediaan yang tergolong mudah rusak seperti PT X, metode First In First Out dapat memberikan paparan penilaian persediaan yang di sesuaikan dengan pergerakan keluar masuknya barang.

Keyword : Inventory, Cost of Goods Sold, Financial Report

Kata kunci : Persediaan, Harga Pokok Penjualan, Laporan Keuangan 


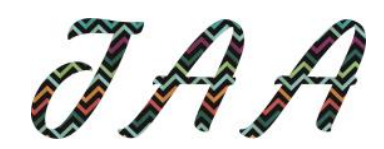

Vol. 6, No. 1, Oktober 2021

\section{PENDAHULUAN}

Persediaan merupakan sekumpulan asset yang dimiliki dengan tujuan untuk dijual kembali dalam kegiatan ekonomi suatu entitas, atau dapat berupa sekumpulan asset yang digunakan dalam proses produksi yang berwujud bahan baku atau barang setengah jadi. Metode penilaian persediaan memiliki peranan penting bagi perhitungan besaran pendapatan yang akan di paparkan dalam laporan keuangan. Hal ini dikarenakan persediaan memiliki posisi strategis dalam dua laporan keuangan sekaligus yaitu dalam paparan laporan laba rugi (sebagai komponen dalam menghitung harga pokok persediaan) dan sebagai salah satu komponen penyusun asset lancar dalam penyajiannya pada neraca (Anwar \& Karamoy, 2014; Naningsih, 2019).

Metode penilaian persediaan pada dasarnya terbagi menjadi tiga yaitu First In First Out (FIFO), Last In First Out (LIFO), dan Average. Namun demikian, metode penilaian yang umum digunakan digunakan adalah metode First In First Out dan Metode Last In First Out. Metode First In First Out umum digunakan karena penilaian persediaan disesuaikan dengan pergerakan persediaan, dimana nilai persediaan dicatat berurutan berdasarkan urutan pergerakan persediaan, dimana persediaan yang pertama kali masuk, akan dicatat sebagai persediaan keluar ketika pertama kali terjadi pergerakan persediaan keluar. Sedangkan Metode Last In First Out, jamak digunakan karena metode ini mencatat nilai persediaan berdasarkan pergerakan persediaan yang masuk terakhir akan dicatat pertama kali nilainya pada saat terjadi pergerakan persediaan keluar. Penggunaan Metode Last In First Out ini dapat menguntungkan perusahaan karena perhitungan nilai persediaan dengan metode Last In First Out ini membuat nilai harga pokok persediaan menjadi lebih besar dan dapat menurunkan laba yang pada akhirnya dapat menurunkan besaran pajak yang harus di bayarkan oleh perusahaan (Aziza, 2019; Sari, 2018).

PSAK No.14 memaparkan bahwa metode penilaian persediaan kecuali untuk barang persediaan yang dibuat khsus untuk proyek tertentu maka metode penilaian persediaan yang digunakan adalah metode Masuk Pertama Keluar Pertama (First In First Out). Selain itu Undang - Undang Nomor 36 Tahun 2008 mengenai perpajakan pasal 10 ayat 6 memaparkan bahwa untuk kepentingan perpajakan metode penilaian persediaan Last In First Out tidak diperkenankan (I. A. Indonesia, 2015).

PT. X adalah Perusahaan yang bergerak dalam bidang distribusi makanan ringan, di Jawa Timur yang mendistribusikan barang dagangannya ke supermarket, toko grosir, maupun outlet kecil lainnya. Karakteristik persediaan PT. $X$ ini merupakan persediaan yang memiliki risiko mudah rusak, karena persediaannya merupakan barang yang dikonsumsi, sehingga PT.X harus memperhatikan arus pergerakan persediaannya dalam melakukan perhitungan penilaian persediaan. Namun demikian, dalam melaksanakan pencatatan nilai persediaannya, PT.X 
menggunakan metode Last In First Out, dimana seharusnya sesuai dengan PSAK No. 14 perusahaan ini menggunakan metode pencatatan First In First Out.

Penelitian ini bertujuan untuk membahas implementasi metode penilaian persediaan First In First Out pada PT.X yang merupakan distributor makanan ringan dan bagaimana dampaknya terhadap pelaporan keuangan PT.X, serta berkontribusi dalam memberikan penjelasan yang mudah dimengerti berkaitan perbandingan implementasi metode penilaian persediaan First In First Out dan Last In First Out.

\section{TELAAH LITERATUR}

Laporan Keuangan merupakan hasil dari proses pencatatan akuntansi yang bisa digunakan sebagai media komunikasi dengan berbagai pihak yang memiliki kepentingan terhadap prospek keuangan perusahaan yang menerbitkan laporan keuangan tersebut. Gambaran keuangan yang dipaparkan dalam Laporan Keuangan dari perusahaan yang bersangkutan ialah paparan dari kegiatan perusahaan tersebut selama satu periode tertentu, yang diantaranya memuat mengenai kemampuan perusahaan untuk melunasi hutangnya, baik hutang jangka Panjang maupun hutang jangka pendek, proyeksi kemampuan perusahaan untuk menghasilkan laba, serta informasi proyeksi tren ekspansi usaha dari perusahaan yang bersangkutan. Dimana informasi tersebut akan sangat berguna bagi para penggunanya terutama untuk pengambilan keputusan ekonomi

Komponen Laporan Keuangan meliputi :

1. Neraca.

Neraca merupakan laporan keuangan yang meliputi informasi yang berkaitan dengan sumber daya yang dimiliki perusahaan dan sumber pendanaan yang digunakan oleh perusahaan yang terdiri dari hutang dan modal (ekuitas) dari perusahaan yang bersangkutan.

2. Laporan Laba Rugi

Laporan Laba Rugi merupakan laporan keuangan yang meliputi informasi mengenai besaran pendapatan dan beban usaha yang terjadi selama satu periode akuntansi di perusahaan yang bersangkutan. Dimana laporan ini memberikan paparan posisi keuangan perusahaan, apakah perusahaan mendapatkan laba atau mengalami kerugian pada periode tersebut.

3. Laporan Arus Kas

Laporan Arus Kas merupakan laporan keuangan yang memaparkan mengenai penerimaan dan pengeluaran kas yang terjadi dalam perusahaan yang bersangkutan selama satu periode akuntansi. Laporan ini terdiri dari tiga bagian yaitu, arus kas yang berkaitan dengan aktivitas operasional perusahaan, arus kas yang berkaitan dengan kegiatan investasi perusahaan dan arus kas yang berkaitan dengan aktivitas pendanaan perusahaan

4. Laporan Perubahan Ekuitas 


\section{$D A A$}

Vol. 6, No. 1, Oktober 2021

Laporan Perubahan Ekuitas merupakan laporan keuangan yang memaparkan perubahan yang terjadi pada ekuitas perusahaan karena adanya aktivitas ekonomi pada perusahaan yang bersangkutan selama satu periode akuntansi.

5. Catatan Atas Laporan Keuangan

Catatan Atas Laporan Keuangan merupakan catatan yang dibuat dengan maksud agar para pengguna laporan keuangan dapat memperoleh informasi yang lebih jelas berkaitan dengan hal - hal yang dipaparkan pada laporan keuangan. Catatan Atas Laporan Keuangan diantaranya memuat hal hal seperti kebijakan akuntansi yang digunakan oleh perusahaan yang bersangkutan maupun penjelasan mengenai pos - pos laporan keuangan.

(B. E. J. D. t. Indonesia, 2016; Pratiwi, Sondakh, \& Kalangi, 2014; Rahmawati, Indahningwati, \& GS, 2020; SUHERTI, 2019; Sulistyowati, 2015; Wehantouw \& Tinangon, 2015; Widyastuti, 2017)

Komponen persediaan merupakan bagian yang penting dalam laporan keuangan, khususnya dalam laporan neraca. Persediaan merupakan sekumpulan asset yang dimiliki dengan tujuan untuk dijual kembali dalam kegiatan ekonomi suatu entitas, atau dapat berupa sekumpulan asset yang digunakan dalam proses produksi yang berwujud bahan baku atau barang setengah jadi. Persediaan memiliki peranan penting dalam laporan keuangan. Pada perusahaan dagang, persediaan memiliki porsi yang cukup besar di neraca, yaitu di bagian asset lancar. Selain itu, persediaan juga memiliki peran penting dalam laporan rugi laba, yakni dalam hal menentukan perhitungan hasil operasional suatu perusahaan dalam satu periode akuntansi (Anwar \& Karamoy, 2014; Mauluddin Nakya Santini, 2017; Wibowo, 2014).

Jenis - Jenis Persediaan

Jenis Persediaan secara umum berdasarkan pemrosesannya terbagi menjadi tiga jenis yaitu :

1. Bahan Mentah

Bahan mentah merupakan jenis persediaan yang dibeli oleh perusahaan dari distributor (supplier) yang digunakan untuk operasional kegiatan produksi perusahaan yang belum di proses. Seperti misalnya, besi, kayu, dan lain lain yang digunakan dalam kegiatan produksi perusahaan.

2. Barang Setengah Jadi

Barang Setengah Jadi merupakan jenis persediaan yang telah di proses dalam suatu kegiatan produksi, namun masih memerlukan aktivitas tambahan sebelum akhirnya masuk kedalam kategori barang jadi.

3. Barang Jadi

Barang Jadi merupakan jenis persediaan yang telah benar benar selesai melewati proses produksi dan siap untuk di jual kepada pihak lain. (Anwar \& Karamoy, 2014; Shofa, Marlyana, \& Bernadhi, 2020; Supriyanti, Romadhon, \& Iskandar, 2015) 
Metode untuk mencatat persediaan didasarkan pada saat pencatatannya. Metode tersebut terbagi menjadi dua kelompok yaitu :

1. Metode Periodik

Metode pencatatan persediaan dengan metode periodic merupakan metode pencatatan persediaan yang dilakukan dengan cara menyelenggarakan perhitungan fisik dari persediaan secara berkala, dimana metode pencatatan ini tidak dilakukan secara berkala pada saat terjadi pergerakan jumlah persediaan atau secara sederhana dapat di nyatakan bahwa metode pencatatan ini dilakukan dengan cara stock opname pada setiap rentang waktu periode yang telah ditentukan oleh perusahaan.

Dalam metode pencatatan persediaan periodic, pembelian barang dagang akan di masukkan kedalam akun pembelian dan tidak dimasukkan kedalam akun persediaan sebagaimana yang di praktekkan dalam metode pencatatan perpetual. Selain itu, dalam metode pencatatan persediaan periodic, penggunaan akun potongan pembelian, retur pembelian dan penyesuaian harga beli akan di jalankan secara terpisah.

2. Metode Perpetual

Metode pencatatan persediaan perpetual merupakan metode pencatatan persediaan yang dilakukan secara berkala pada saat setiap terjadi pergerakan jumlah persediaan. Dalam metode pencatatan persediaan perpetual ini, pencatatan tentang harga pokok dari setiap persediaan barang dagangan yang dibeli oleh perusahaan dan juga yang dijual, di laksanakan dengan rinci, dimana pada saat perusahaan membeli persediaan maka perusahaan akan mendebet akun persediaan barang dagangan, dan pada saat perusahaan menjual barang dagangan, perusahaan tidak hanya mencatata penjualannya saja, tetapi juga menyertakan pencatatan mengenai harga pokok barang dagangan yang terjual. Dengan metode pencatatan persediaan perpetual ini maka perusahaan tidak perlu melakukan penghitungan jumlah barang dagang atau nilai persediaan pada setiap akhir periode, karena pencatatan tersebut sudah dilakukan pada saat setiap terjadi pergerakan persediaan barang dagangan (DEIRA KIRNIYANTI, 2016; Karundeng, Saerang, \& Gamaliel, 2017)

Terdapat tiga metode yang umum digunakan untuk menghitung nilai dari persediaan yaitu :

1. Metode FIFO

Metode penilaian persediaan ini menghitung nilai persediaan terjual dengan mengurutkan mulai dari menhitung nilai barang yang pertama kali dibeli yang dicatat dengan disesuaikan terhadap arus fisik barang. Sesuai dengan namanya, yaitu FIFO yaitu First In Fist Out yang secara harfiah dapat diterjemahkan sebagai barang yang pertama masuk adalah yang pertama keluar. Metode pencatatan nilai persediaan ini dinilai lebih realistis 
karena melakukan perhitungan nilai persediaan yang dijual berdasarkan nilai persediaan yang pertama kali masuk.

Metode perhitungan nilai persediaan FIFO ini dalam kondisi normal dapat menyajikan nilai persediaan dalam besaran yang wajar dalam laporan keuangan. Selain itu, untuk kepentingan pemaparan profitabilitas, besaran laba yang disajikan dalam laporan keuangan setelah menggunakan metode perhitungan FIFO akan lebih besar dibandingkan dengan metode yang lain. Namun demikian penggunaan metode perhitungan FIFO pada saat yang bersamaan juga akan mendorong pada potongan pajak yang lebih besar, berkenaan dengan besaran nominal laba yang disajikan dalam laporan keuangan.

2. Metode LIFO

Metode penilaian persediaan ini menghitung nilai persediaan terjual dengan mengurutkan mulai dari nilai barang yang paling akhir dibeli (paling baru) diurutkan sampai dengan barang yang paling pertama dibeli, dengan asumsi bahwa barang yang paling akhir dibeli adalah barang yang terjual terlebih dahulu. Metode penilaian persediaan LIFO ini acapkali mendapatkan kritikan secara konsep karena pengaplikasian metode ini menghasilkan perhitungan nilai harga pokok persediaan yang tinggi dan jumlah laba kotor yang lebih rendah. Namun demikian, jika metode ini digunakan pada saat periode inflasi, maka metode ini dapat dikatakan mampu untuk menggambarkan kondisi yang realistis karena pada saat terjadi kenaikan harga maka metode LIFO ini akan mengaitkan biaya dengan besaran yang tinggi yang sesuai dengan biaya perolehan persediaan dengan harga jual yang melambung pada saat terjadinya inflasi. Namun demikian, jika metode LIFO ini digunakan dalam jangka waktu yang Panjang maka akan semakin terlihat selisih yang cukup besar antara perhitungan nilai persediaan dengan metode penilaian persediaan FIFO dan LIFO. Metode penilaian ini hanya dapat digunakan pada jenis persediaan tertentu saja. Misalnya persediaan yang memiliki masa simpan yang cukup lama atau untuk persediaan yang semakin baik kualitasnya jika masa simpannya semakin lama. Sedangkan untuk jenis persediaan yang tidak memiliki ketahanan yang lama, maka metode penilaian persediaan LIFO ini tidak cocok jika digunakan.

3. Metode Average

Metode penilaian persediaan ini menghitung nilai persediaan terjual dengan menghitung rata - rata nilai persediaan dan membebankannya ke setiap unit persediaan. Metode ini mengasumsikan bahwa setiap persediaan yang terjual memiliki harga yang rata - rata sama. Metode ini tidak memperhatikan wakti dibelinya setiap persediaan (apakah persediaan tersebut dibeli di awal periode ataukah dibeli di akhir periode). Hasil perhitungan nilai persediaan yang menggunakan metode ini akan berada ditengah diantara perhitungan nilai persediaan FIFO dan LIFO .(Anwar \& Karamoy, 2014; Aziza, 2019; Sari, 2018; Warni, 2016) 
Metode rata - rata tertimbang ini memiliki keunggulan dalam hal bahwa metode ini akan memberikan kepraktisan ketika terjadi suatu kondisi dimana sangat sulit atau tidak mungkin melakukan identifikasi terhadap arus fisik persediaan, maka menghitung dengan merata - rata kan harga pokok suatu persediaan dapat menjadi cara yang paling tepat, dimana metode ini membebankan biaya pada besaran yang sama terhadap persediaan yang homogen. Namun demikian metode ini juga memiliki keterbatasan dalam hal bahwa nilai pembebanan terhadap persediaan tersebut akan terus mengandung pengaruh dari biaya persediaan yang paling awal dimana nilai tersebut dapat menyebabkan selisih yang signifikan pada akhir periode terhadap harga sekarang (current price), terutama ketika berada pada suatu periode dimana terjadi pergerakan harga yang cukup cepat (Abdullah, Djalil, \& Informasi, 2017)

PSAK 14 memaparkan mengenai penggunaan metode penilaian persediaan. Dalam PSAK 14 paragraph 25 di paparkan bahwa biaya persediaan kecuali biaya untuk persediaan yang secara umum tidak dapat ditukar dengan persediaan lain dan barang atau jasa yang dihasilkan untuk proyek tertentu yang di hitung berdasarkan identifikasi khusus terhadap biaya masing masing maka dihitung dengan menggunakan rumus biaya masuk pertama keluar pertama (First In First Out). Dimana entitas menggunakan rumus biaya yang sama untuk seluruh persediaan yang memiliki sifat dan kegunaan yang sama. Dari penjelasan tersebut dapat disimpulkan bahwa untuk perusahaan dengan jenis persediaan yang bukan barang dengan spesifikasi khusus, maka perhitungan nilai persediaannya tidak diarahkan untuk menggunakan metode LIFO, melainkan menggunakan metode FIFO. Selain itu, penggunaan metode penilaian persediaan LIFO dalam perhitungan nilai persediaan dapat menyebabkan laba perusahaan bernilai lebih rendah, dan pada akhirnya pembayaran nominal pajak menjadi lebih rendah, dimana hal tersebut merujuk pada Undang - Undang Nomor 36 Tahun 2008 mengenai peraturan perpajakan pasal 10 ayat 6 (Darwati, Slamet, \& Maimunah, 2019; I. A. Indonesia, 2015; Lestari, 2017; Setiawan, 2020)

Beberapa Penelitian terdahulu yang mendasari dilakukannya penelitian ini diantaranya adalah :

1. Penelitian yang dilakukan oleh Dian (2018) yang memaparkan mengenai perbandingan penerapan metode perhitungan nilai persediaan FIFO LIFO dan Average pada perusahaan yang menjual gas elpiji yang termasuk dalam golongan barang yang memiliki sifat yang beresiko mudah rusak.. Penelitian ini dilakukan dengan menggunakan menggunakan metode penelitian kualitatif. Hasil dari penelitian ini memaparkan bahwa pada perusahaan dengan tipe persediaan yang mudah rusak seperti ini, maka metode penilaian persediaan yang cocok digunakan adalah metode FIFO. Karena penghitungan nilai persediaan akan disesuaikan dengan aliran persediaan yang terjual, dimana pada perusahaan dengan jenis persediaan seperti ini 
tentunya akan menjual persediaan yang lebih awal masuk ke gudang perusahaan.

2. Penelitian yang dilakukan oleh Anwar dan Karamoy (2014) yang memaparkan mengenai perbandingan penerapan metode perhitungan nilai persediaan FIFO LIFO dan Average pada perusahaan yang menjual air minum dalam kemasan (AMDK) yang termasuk dalam golongan barang yang memiliki sifat yang beresiko mudah rusak.. Penelitian ini dilakukan dengan menggunakan menggunakan metode penelitian kualitatif. Hasil dari penelitian ini memaparkan bahwa pada perusahaan dengan tipe persediaan yang mudah rusak seperti ini, maka metode penilaian persediaan yang cocok digunakan adalah metode FIFO. Karena penghitungan nilai persediaan akan disesuaikan dengan aliran persediaan yang terjual, dimana pada perusahaan dengan jenis persediaan seperti ini tentunya akan menjual persediaan yang lebih awal masuk ke gudang perusahaan.

\section{METODE PENELITIAN}

Penelitian ini dilakukan dengan metode kualitatif deskriptif dengan pendekatan studi kasus. Pendekatan tersebut bertujuan untuk membuat pemaparan secara cermat mengenai fenomena tertentu, yang kemudian dibandingkan dengan praktek yang terjadi di lapangan. Pengumpulan data dalam penelitian ini dilakukan melalui tahapan observasi, wawancara, dan dokumentasi (Anggito \& Setiawan, 2018). Penelitian ini dilakukan pada PT. $X$ yang merupakan distributor makanan nasional yang berlokasi di Surabaya. Data yang digunakan dalam penelitian ini adalah data primer yang didapatkan dari catatan persediaan serta laporan keuangan perusahaan.

\section{HASIL PENELITIAN DAN PEMBAHASAN}

PT.X merupakan perusahaan distributor makanan ringan yang didirikan pada tahun 2015 di Jawa Timur. PT . X mendistribusikan makanan ringan tersebut dari produsen (pabrik) melalui supermarket, toko grosir maupun outlet kecil. Pencatatan persediaan yang dilakukan oleh PT X menggunakan metode Last In First Out (LIFO). Adapun pemaparan jumlah persediaan dan laporan keuangan dari PT X adalah sebagai berikut :

\section{Tabel 1}

Jumlah Pembelian dan Penjualan PT X Tahun 2018

\begin{tabular}{rlccccc}
\hline No & \multicolumn{1}{c}{ Bulan } & Harga & Pembelian (Unit) & Penjualan (Unit) & Nilai Persediaan Awal & Pembelian \\
\hline 1 & Desember 2017 & 137.500 & 5.000 & & 687.500 .000 & \\
2 & Januari 2018 & 139.600 & 9.500 & 11.000 & & 1.326 .200 .000 \\
3 & Februari 2018 & 146.080 & 10.500 & 10.000 & & 1.533 .840 .000 \\
4 & Maret - April 2018 & 160.151 & 12.500 & 11.700 & & 2.001 .887 .500 \\
5 & Mei 2018 & 178.169 & 10.100 & 11.100 & & 1.799 .506 .900 \\
6 & Juni 2018 & 188.900 & 10.200 & 10.900 & \\
7 & Juli - Agustus 2018 & 200.500 & 10.500 & 9.500 & \\
8 & September 2018 & 211.900 & 21.000 & 20.000 & & 2.105 .250 .000 \\
9 & Oktober 2018 & 224.050 & 16.000 & 11.000 & & 3.449 .900 .000 \\
& & & & & 3.584 .800 .000
\end{tabular}




\begin{tabular}{rrrrrr}
10 & November 2018 & 236.893 & 19.000 & 11.000 & 4.500 .967 .000 \\
11 & Desember 2018 & 250.900 & 31.150 & 18.800 & 7.815 .535 .000 \\
\hline \multicolumn{3}{c}{ Total Pembelian } & & $\mathbf{3 1 . 0 4 4 . 6 6 6 . 4 0 0}$ \\
\hline
\end{tabular}

Sumber : Data Primer

\begin{tabular}{lr}
\hline \multicolumn{2}{c}{ TABEL 2 } \\
\multicolumn{2}{c}{ PERHITUNGAN HARG POKOK PERSEDIAAN TAHUN } \\
2018 (NILAI PERSEDIAAN METODE LIFO) \\
\hline Persediaan Awal & 687.500 .000 \\
Pembelian Persediaan & 31.044 .666 .400 \\
Tersedia untuk dijual & 31.732 .166 .400 \\
Persediaan Akhir & 6.952 .659 .000 \\
Harga Pokok Persediaan & $\mathbf{2 4 . 7 7 9 . 5 0 7 . 4 0 0}$ \\
\hline
\end{tabular}

Sumber : Data Diolah

\section{Tabel 3}

NERACA PT X 2018 (NILAI PERSEDIAAN METODE LIFO)

\section{ASET}

\section{ASET LANCAR}

Kas dan Bank

Piutang Usaha

Piutang Lain

Pihak Hubungan Istimewa

Pihak Ketiga

Persediaan

Beban dibayar Dimuka

Pajak dibayar Dimuka

Jumlah Aset Lancar

\section{ASET TIDAK LANCAR}

Piutang Pemegang Saham

Taksiran Tagihan Pajak Penghasilan

Aset Tetap - Setelah dikurangi

Akumulasi Penyusutan

Jumlah Aset Tidak Lancar
473.115 .562

3.162 .637 .892

1.687.804.000

349.593 .717

6.952 .659 .000

15.585 .382

12.641.395.553

393.932 .904

9.650 .648

117.076.907

$\mathbf{5 2 0 . 6 6 0 . 4 5 9}$

13.162.056.012
KEWAJIBAN DAN EKUITAS KEWAJIBAN JANGKA PENDEK

Utang Bank Jangka Pendek

7.363.017.558

Utang Usaha - Pihak Ketiga

2.345.510.157

Biaya yang Masih Harus dibayar

Utang Pajak

897.433

Jumlah Kewajiban Jangka Pendek

KEWAJIBAN JANGKA PANJANG

Kewajiban Imbalan Kerja

Jumlah Kewajiban Jangka Panjang

81.991 .656

81.991 .656

JUMLAH KEWAJIBAN

EKUITAS

9.791.416.804

Modal Saham

Modal dasar : 1000 Lembar @ Rp. 1.000 .000

Modal dasar yang ditempatkan

dan disetor

secara penuh : 500 lembar @ Rp.

1.000 .000

500.000 .000

2.870.639.208

JUMLAH EKUITAS

JUMLAH KEWAJIBAN DAN

3.370.639.208

EKUITAS

Sumber : Data Diolah

\section{Tabel 4}

LAPORAN RUGI LABA 2018 (NILAI PERSEDIAAN METODE LIFO)

Penjualan Bersih

33.413 .955 .260 


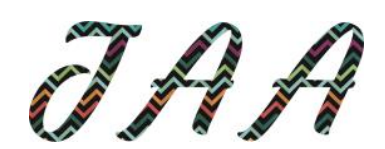

Vol. 6, No. 1, Oktober 2021

\begin{tabular}{|c|c|}
\hline Harga Pokok Penjualan & 24.779 .507 .400 \\
\hline Laba Kotor & 8.634 .447 .860 \\
\hline \multicolumn{2}{|l|}{ Beban Usaha } \\
\hline Beban Operasional & 2.185 .185 .686 \\
\hline \multirow[t]{2}{*}{ Beban Administrasi } & 798.603 .784 \\
\hline & 2.983.789.470 \\
\hline Laba (Rugi) Usaha & 5.650 .658 .390 \\
\hline \multicolumn{2}{|c|}{$\begin{array}{c}\text { Tabel } 4 \text { (Cont.) } \\
\text { LAPORAN RUGI LABA } 2018 \text { (NILAI PERSEDIAAN METODE LIFO) }\end{array}$} \\
\hline Pendapatan Lain Lain Bersih & 1.281 .617 .790 \\
\hline Laba sebelum Pajak Penghasilan & 6.932.276.180 \\
\hline \multicolumn{2}{|l|}{ Pajak Penghasilan } \\
\hline Beban Pajak Kini & \\
\hline Laba Bersih & 6.932 .276 .180 \\
\hline
\end{tabular}

Sumber : Data Diolah

PSAK No 14 revisi tahun 2008 disebutkan bahwa metode penilaian persediaan yang umum digunakan adalah metode Masuk Pertama Keluar Pertama atau disebut dengan First In First Out (FIFO). Sedangkan metode Last In First Out (LIFO) hanya boleh dipergunakan untuk perusahaan yang memiliki jenis persediaan yang di produksi dengan pesanan khusus, dimana persediaan tersebut memiliki spesifikasi khusus yang tidak dapat digantikan dengan barang yang lain (I. A. Indonesia, 2015). Selain itu, PT X merupakan perusahaan dengan persediaan yang termasuk kategori cepat rusak sehingga metode Masuk Pertama Keluar Pertama atau First In First Out akan lebih cocok digunakan karena penilaian atas nilai persediaannya akan menyesuaikan dengan arus pergerakan persediaan (Sari, 2018). Adapun perhitungan nilai persediaan ketika PT X menggunakan metode Masuk Pertama Keluar Pertama atau First In First Out adalah sebagai berikut :

\begin{tabular}{lr}
\hline \multicolumn{2}{c}{ Tabel 5} \\
\multicolumn{2}{c}{ PERHITUNGAN HARGA POKOK PERSEDIAAN TAHUN } \\
2018 (NILAI PERSEDIAAN METODE FIFO) \\
\hline Persediaan Awal & 687.500 .000 \\
Pembelian Persediaan & 31.044 .666 .400 \\
Tersedia untuk dijual & 31.732 .166 .400 \\
Persediaan Akhir & 7.389 .005 .000 \\
Harga Pokok Persediaan & $\mathbf{2 4 . 3 4 3 . 1 6 1 . 4 0 0}$ \\
\hline
\end{tabular}

Sumber : Data Diolah

Tabel 6

NERACA PT X 2018 (NILAI PERSEDIAAN METODE FIFO) 


\footnotetext{
Kas dan Bank

Piutang Usaha

Piutang Lain

Pihak Hubungan Istimewa

Pihak Ketiga

Persediaan

Beban dibayar Dimuka

Pajak dibayar Dimuka

Jumlah Aset Lancar

\section{ASET TIDAK LANCAR}

Piutang Pemegang Saham

Taksiran Tagihan Pajak

Penghasilan

Aset Tetap - Setelah dikurangi

Akumulasi Penyusutan

Jumlah Aset Tidak Lancar
}

473.115 .562

3.162 .637 .892

1.687.804.000

349.593 .717

7.389.005.000

15.585 .382

13.077.741.553

117.076.907

$\mathbf{5 2 0 . 6 6 0 . 4 5 9}$
Utang Bank Jangka Pendek

Utang Usaha - Pihak Ketiga

Biaya yang Masih Harus dibayar

$$
\text { Utang Pajak }
$$

Jumlah Kewajiban Jangka Pendek

\section{KEWAJIBAN JANGKA PANJANG}

Kewajiban Imbalan Kerja

Jumlah Kewajiban Jangka Panjang

\section{JUMLAH KEWAJIBAN}

\section{EKUITAS}
393.932.904 Modal Saham
Modal dasar : 1000 Lembar @ Rp.
$9.650 .648 \quad 1.000 .000$
Modal dasar yang ditempatkan dan disetor
secara penuh : 500 lembar @ Rp.

1.000 .000

JUMLAH EKUITAS

JUMLAH KEWAJIBAN DAN

13.598.402.012 EKUITAS
500.000 .000

3.306.985.208

7.363.017.558

2.345.510.157

897.433

9.709.425.148

81.991 .656

81.991 .656

9.791.416.804

3.806.985.208

JUMLAH ASET

\section{Sumber : Data Diolah}

Tabel 7

\begin{tabular}{lr}
\multicolumn{2}{c}{ Tabel 7 } \\
LAPORAN RUGI LABA TAHUN 2018 (NILAI PERSEDIAAN METODE FIFO) \\
\hline Penjualan Bersih & 33.413 .955 .260 \\
Harga Pokok Penjualan & 24.343 .161 .400 \\
Laba Kotor & $\mathbf{9 . 0 7 0 . 7 9 3 . 8 6 0}$ \\
& \\
Beban Usaha & 2.185 .185 .686 \\
$\quad$ Beban Operasional & 798.603 .784 \\
$\quad$ Beban Administrasi & $\mathbf{2 . 9 8 3 . 7 8 9 . 4 7 0}$ \\
& $\mathbf{6 . 0 8 7 . 0 0 4 . 3 9 0}$ \\
Laba (Rugi) Usaha & 1.281 .617 .790 \\
Pendapatan Lain Lain Bersih & $\mathbf{7 . 3 6 8 . 6 2 2 . 1 8 0}$ \\
Laba sebelum Pajak Penghasilan & \\
Pajak Penghasilan & \\
$\quad$ Beban Pajak Kini & \\
\hline Laba Bersih & $\mathbf{7 . 3 6 8 . 6 2 2 . 1 8 0}$ \\
\hline
\end{tabular}

Sumber : Data Diolah

Dari pemaparan diatas dapat dilihat bahwa paparan besaran persediaan pada neraca dengan perhitungan nilai persediaan yang menggunakan metode First In First Out dan neraca dengan perhitungan nilai persediaan yang menggunakan metode Last In First Out memiliki selisih besaran yang cukup besar yakni sebesar Rp. 436.346.000, dimana 


\section{$D A A$}

Vol. 6, No. 1, Oktober 2021

hal tersebut juga di paparkan pada laporan rugi laba dengan besaran selisih yang sama, yakni pada besaran laba bersih antara laporan laba rugi yang harga pokok persediaanya dihitung menggunakan metode Last In First Out dan laporan laba rugi yang harga pokok persediaannya dihitung menggunakan metode First In First Out. Selisih tersebut cukup signifikan mengigat besaran selisih tersebut mencapai $6 \%$ dari nilai laba bersih PT. X.

\section{SIMPULAN}

Perhitungan metode penilaian persediaan yang telah dipaparkan diatas menunjukkan bahwa nilai harga pokok persediaan PT. X menjadi lebih kecil ketika menggunakan metode penilaian persediaan First In First Out (FIFO), sehingga nilai laba dalam laporan rugi laba menjadi lebih tinggi dengan selisih yang cukup besar jika dibandingkan ketika perusahaan menggunakan metode penilaian persediaan First In First Out dan metode penilaian persediaan Last In First Out (LIFO). Namun demikian, nilai persediaan yang telah dihitung dengan menggunakan metode First In First Out (FIFO) tersebut telah mencerminkan nilai yang lebih wajar dibandingkan dengan menggunakan metode Last In First Out (LIFO), karena pencatatan nilai persediaan pada PT. X yang persediaannya tergolong mudah rusak, telah disesuaikan dengan urutan pergerakan barang.

Namun demikian, penelitian ini masih memiliki keterbatasan, perihal rentang data yang mampu untuk didapatkan dalam rangka membuat perbandingan antara penerapan metode penilaian persediaan First In First Out (FIFO) dan metode penilaian persediaan Last In First Out (LIFO) pada PT X, dimana data keuangan yang bisa didapatkan hanya satu tahun saja. Penelitian selanjutnya diharapkan dapat memberikan pemaparan yang lebih detil dengan rentang data yang lebih panjang agar bisa didapatkan penjelasan yang lebih mendalam mengenai perbandingan penerapan metode penilaian persediaan First In First Out (FIFO) dan Last In First Out (LIFO).

\section{DAFTAR PUSTAKA}

Abdullah, S., Djalil, M. A. J. M. R. A., Auditing, \& Informasi. (2017). Apakah metode FIFO dan rata-rata memang berbeda: Bukti empiris dari Bursa Efek Jakarta. $4(2), 151-172$.

Anggito, A., \& Setiawan, J. (2018). Metodologi penelitian kualitatif: CV Jejak (Jejak Publisher).

Anwar, N. F., \& Karamoy, H. J. J. E. J. R. E., Manajemen, Bisnis dan Akuntansi. (2014). Analisis penerapan metode pencatatan dan penilaian terhadap persediaan barang menurut PSAK No. 14 pada PT. Tirta Investama DC Manado. 2(2).

Aziza, N. L. (2019). PENENTUAN HARGA POKOK PENJUALAN BERAS DAN JAGUNG PADA UD BAROKAH MOJOKERTO. Politeknik NSC Surabaya,

Darwati, A., Slamet, B., \& Maimunah, S. J. J. O. M. B. A. (2019). ANALISIS PERLAKUAN AKUNTANSI ATAS PERSEDIAAN BARANG DAGANG TERHADAP 
PENYAJIAN AKUN PERSEDIAAN PADA KOPERASI KARYAWAN GOODYEAR. $5(5)$.

DEIRA KIRNIYANTI, K. (2016). ANALISIS PENERAPAN METODE PENCATATAN DAN PENILAIAN PERSEDIAAN BARANG DAGANG PADA PD PANCA MOTOR $P A L E M B A N G$. Politeknik Negeri Sriwijaya,

Indonesia, B. E. J. D. t. (2016). Laporan Keuangan. 20.

Indonesia, I. A. (2015). Pernyataan Standar Akuntansi Keuangan (PSAK) No. 14 Persediaan. In: Jakar-ta.

Karundeng, A., Saerang, D., \& Gamaliel, H. J. G. C. J. R. A. (2017). Analisis Perlakuan Akuntansi Atas Persediaan Barang Jadi Sesuai Dengan Psak No. 14 Pada PT. Fortuna Inti Alam. 12(01).

Lestari, A. (2017). ANALISIS PERBANDINGAN PRAKTIK INCOME SMOOTHING SEBELUM DAN SESUDAH PENERAPAN PSAK BERBASIS IFRS. IIB DARMAJAYA,

Mauluddin Nakya Santini, S. J. P. S. F. U. (2017). Sistem Informasi Persediaan Dan Penjualan Barang Berbasis Desktop Di D-Net House. 2.

Naningsih, N. (2019). Analisis Akuntansi Persediaan dan Pengaruhnya terhadap Laba pada CV. BINTANG TIMUR JAYA. (Bachelor), Universitas Muhammadiyah Makassar Makassar.

Pratiwi, A. A., Sondakh, J. J., \& Kalangi, L. J. J. E. J. R. E., Manajemen, Bisnis dan Akuntansi. (2014). Analisis penerapan SAK ETAP pada penyajian laporan keuangan PT. Nichindo Manado Suisan. 2(3).

Rahmawati, A., Indahningwati, A., \& GS, A. D. J. E. (2020). PENGARUH KEMAMPUAN TEKNIS AUDITOR TERHADAP KUALITAS INFORMASI LAPORAN KEUANGAN. 4(4), 441-461.

Sari, D. I. J. J. P. (2018). Analisis Perhitungan Persediaan dengan Metode FIFO dan Average Pada PT. Harapan. 16(1), 31-38.

Setiawan, F. C. (2020). Analisis Pemilihan Metode Penilaian Persediaan untuk Perencanaan Pajak Penghasilan Badan pada CV. Galaxy Mas. Universitas 17 Agustus 1945 Surabaya,

Shofa, M., Marlyana, N., \& Bernadhi, B. D. J. P. K. I. M. U. K. E. (2020). ANALISA DAMPAK PENGENDALIAN PERSEDIAAN BAHAN BAKU DAGING AYAM PADA UMKM MENGGUNAKAN PENDEKATAN METODE EOQ DENGAN MEMPERTIMBANGKAN MASA KADALUARSA DAN PEMBERIAN DISKON (Studi Kasus Pada Gerai Ayam Zee Chicken Cetar di Semarang).

SUHERTI, E. (2019). Analisa rasio terhadap laporan keuangan pada pt. bank pembangunan daerah sumatera barat.

Sulistyowati, N. W. J. A. J. A. d. P. (2015). Analisis Laporan Keuangan Sebagai Alat Untuk Menilai Kinerja Keuangan Pt Pelabuhan Indonesia Iii Surabaya. 4(2), 125-133.

Supriyanti, D., Romadhon, Y. B., \& Iskandar, D. J. J. C. (2015). Sistem Informasi Persediaan Barang Pada Pt. hankook Ceramic Indonesia. 1(1), 56-63. 


\section{JAA}

Vol. 6, No. 1, Oktober 2021

Warni, S. (2016). Perusahaan Ini Cocok Menggunakan Metode LIFO. Accounting. Retrieved from https://blog.zahiraccounting.com/perusahaan-ini-cocokmenggunakan-metode-lifo/

Wehantouw, A. B., \& Tinangon, J. J. J. J. E. J. R. E., Manajemen, Bisnis dan Akuntansi. (2015). Analisis Laporan Arus Kas Operasi, Investasi dan Pendanaan pada PT. Gudang Garam Tbk. 3(1).

Wibowo, E. M. J. J. I. A. K. (2014). Pengaruh Persediaan Terhadap Peningkatan Profitabilitas Perusahaan. 2(1), 001-008.

Widyastuti, P. (2017). Pencatatan Laporan Keuangan Berbasis Standar Akuntansi Keuangan Entitas Tanpa Akuntabilitas (SAK ETAP) Pada Usaha Mikro Kecil Menengah (UMKM) di Bidang Jasa. Journal For Business Enttrepreneurship, 1(1). 
Annisa Rahmawati \& Achmad Daengs : Implementasi Metode FIFO Dalam Perhitungan Nilai Persediaan Pada Pt.X Distributor Makanan..........

\begin{tabular}{|c|c|c|c|c|c|c|c|c|c|}
\hline \multicolumn{10}{|c|}{ LAMPIRAN } \\
\hline \multicolumn{10}{|c|}{$\begin{array}{c}\text { LAMPIRAN } 1 \\
\text { TABEL PERHITUNGAN NILAI PERSEDIAAN METODE LIFO }\end{array}$} \\
\hline & \multicolumn{3}{|c|}{ Pembelian } & \multicolumn{3}{|c|}{ Penjualan } & \multicolumn{3}{|c|}{ Saldo } \\
\hline Tanggal & Unit & Harga & Total & Unit & Harga & Total & Unit & Harga & Total \\
\hline Desember 2017 & & & & & & & 5.000 & 137.500 & 687.500 .000 \\
\hline \multirow[t]{4}{*}{ Januari 2018} & 9.500 & 139.600 & 1.326 .200 .000 & & & & 9.500 & 139.600 & 1.326 .200 .000 \\
\hline & & & & & & & 5.000 & 137.500 & 687.500 .000 \\
\hline & & & & 9.500 & 139.600 & 1.326 .200 .000 & & & \\
\hline & & & & 1.500 & 137.500 & 206.250 .000 & 3.500 & 137.500 & 481.250 .000 \\
\hline \multirow[t]{5}{*}{ Februari 2018} & 10.500 & 146.080 & 1.533 .840 .000 & & & & 10.500 & 146.080 & 1.533 .840 .000 \\
\hline & & & & & & & 3.500 & 137.500 & 481.250 .000 \\
\hline & & & & 10.000 & 146.080 & 1.460 .800 .000 & & & \\
\hline & & & & & & & 500 & 146.080 & 73.040 .000 \\
\hline & & & & & & & 3.500 & 137.500 & 481.250 .000 \\
\hline \multirow[t]{4}{*}{$\begin{array}{l}\text { Maret - April } \\
2018\end{array}$} & 12.500 & 160.151 & 2.001.887.500 & & & & 12.500 & 160.151 & 2.001.887.500 \\
\hline & & & & & & & 500 & 146.080 & 73.040 .000 \\
\hline & & & & & & & 3.500 & 137.500 & 481.250 .000 \\
\hline & & & & 11.700 & 160.151 & 1.873 .766 .700 & & & \\
\hline
\end{tabular}


Vol. 6, No. 1, Oktober 2021

\begin{tabular}{|c|c|c|c|c|c|c|c|c|c|}
\hline & & & & & & & 800 & 160.151 & 128.120 .800 \\
\hline & & & & & & & 500 & 146.080 & 73.040 .000 \\
\hline & & & & & & & 3.500 & 137.500 & 481.250 .000 \\
\hline Mei 2018 & 10.100 & 178.169 & 1.799 .506 .900 & & & & 10.100 & 178.169 & 1.799 .506 .900 \\
\hline & & & & & & & 800 & 160.151 & 128.120 .800 \\
\hline & & & & & & & 500 & 146.080 & 73.040 .000 \\
\hline & & & & & & & 3.500 & 137.500 & 481.250 .000 \\
\hline & & & & 10.100 & 178.169 & 1.799 .506 .900 & & & \\
\hline & & & & 800 & 160.151 & 128.120 .800 & & & \\
\hline & & & & 200 & 146.080 & 29.216 .000 & 300 & 146.080 & 43.824 .000 \\
\hline & & & & & & & 3.500 & 137.500 & 481.250 .000 \\
\hline Juni 2018 & 10.200 & 188.900 & 1.926 .780 .000 & & & & 10.200 & 188.900 & 1.926 .780 .000 \\
\hline & & & & & & & 300 & 146.080 & 43.824 .000 \\
\hline & & & & & & & 3.500 & 137.500 & 481.250 .000 \\
\hline & & & & 10.200 & 188.900 & 1.926 .780 .000 & & & \\
\hline & & & & 300 & 146.080 & 43.824 .000 & & & \\
\hline & & & & 400 & 137.500 & 55.000 .000 & & & \\
\hline & & & & & & & 3.100 & 137.500 & 426.250 .000 \\
\hline
\end{tabular}


Annisa Rahmawati \& Achmad Daengs : Implementasi Metode FIFO Dalam Perhitungan Nilai Persediaan Pada Pt.X Distributor Makanan..........

\begin{tabular}{|c|c|c|c|c|c|c|c|c|c|}
\hline \multirow[t]{5}{*}{$\begin{array}{l}\text { Juli - Agustus } \\
2018\end{array}$} & 10.500 & 200.500 & 2.105 .250 .000 & & & & 10.500 & 200.500 & 2.105 .250 .000 \\
\hline & & & & & & & 3.100 & 137.500 & 426.250 .000 \\
\hline & & & & 9.500 & 200.500 & 1.904 .750 .000 & & & \\
\hline & & & & & & & 1.000 & 200.500 & 200.500 .000 \\
\hline & & & & & & & 3.100 & 137.500 & 426.250 .000 \\
\hline \multirow[t]{7}{*}{ September 2018} & 21.000 & 211.900 & 4.449 .900 .000 & & & & 21.000 & 211.900 & 4.449 .900 .000 \\
\hline & & & & & & & 1.000 & 200.500 & 200.500 .000 \\
\hline & & & & & & & 3.100 & 137.500 & 426.250 .000 \\
\hline & & & & 20.000 & 211.900 & 4.238 .000 .000 & & & \\
\hline & & & & & & & 1.000 & 211.900 & 211.900 .000 \\
\hline & & & & & & & 1.000 & 200.500 & 200.500 .000 \\
\hline & & & & & & & 3.100 & 137.500 & 426.250 .000 \\
\hline \multirow[t]{6}{*}{ Oktober 2018} & 16.000 & 224.050 & 3.584 .800 .000 & & & & 16.000 & 224.050 & 3.584 .800 .000 \\
\hline & & & & & & & 1.000 & 211.900 & 211.900 .000 \\
\hline & & & & & & & 1.000 & 200.500 & 200.500 .000 \\
\hline & & & & & & & 3.100 & 137.500 & 426.250 .000 \\
\hline & & & & 11.000 & 224.050 & 2.464 .550 .000 & & & \\
\hline & & & & & & & 5.000 & 224.050 & 1.120 .250 .000 \\
\hline
\end{tabular}


Vol. 6, No. 1, Oktober 2021

\begin{tabular}{|c|c|c|c|c|c|c|c|c|}
\hline & & & & & & 1.000 & 211.900 & 211.900 .000 \\
\hline & & & & & & 1.000 & 200.500 & 200.500 .000 \\
\hline & & & & & & 3.100 & 137.500 & 426.250 .000 \\
\hline \multirow[t]{11}{*}{ November 2018} & 19.000 & 236.893 & 4.500 .967 .000 & & & 19.000 & 236.893 & 4.500 .967 .000 \\
\hline & & & & & & 5.000 & 224.050 & 1.120 .250 .000 \\
\hline & & & & & & 1.000 & 211.900 & 211.900 .000 \\
\hline & & & & & & 1.000 & 200.500 & 200.500 .000 \\
\hline & & & & & & 3.100 & 137.500 & 426.250 .000 \\
\hline & & & & 11.000 & $236.893 \quad 2.605 .823 .000$ & & & \\
\hline & & & & & & 8.000 & 236.893 & 1.895 .144 .000 \\
\hline & & & & & & 5.000 & 224.050 & 1.120 .250 .000 \\
\hline & & & & & & 1.000 & 211.900 & 211.900 .000 \\
\hline & & & & & & 1.000 & 200.500 & 200.500 .000 \\
\hline & & & & & & 3.100 & 137.500 & 426.250 .000 \\
\hline \multirow[t]{4}{*}{ Desember 2018} & 31.150 & 250.900 & 7.815.535.000 & & & 31.150 & 250.900 & 7.815 .535 .000 \\
\hline & & & & & & 8.000 & 236.893 & 1.895 .144 .000 \\
\hline & & & & & & 5.000 & 224.050 & 1.120 .250 .000 \\
\hline & & & & & & 1.000 & 211.900 & 211.900 .000 \\
\hline
\end{tabular}


Annisa Rahmawati \& Achmad Daengs : Implementasi Metode FIFO Dalam Perhitungan Nilai Persediaan Pada Pt.X Distributor Makanan..........

\begin{tabular}{|c|c|c|c|c|c|c|}
\hline & & & & 1.000 & 200.500 & 200.500 .000 \\
\hline & & & & 3.100 & 137.500 & 426.250 .000 \\
\hline & 18.800 & 250.900 & 4.716 .920 .000 & & & \\
\hline & & & & 12.350 & 250.900 & 3.098 .615 .000 \\
\hline & & & & 8.000 & 236.893 & 1.895 .144 .000 \\
\hline & & & & 5.000 & 224.050 & 1.120 .250 .000 \\
\hline & & & & 1.000 & 211.900 & 211.900 .000 \\
\hline & & & & 1.000 & 200.500 & 200.500 .000 \\
\hline & & & & 3.100 & 137.500 & 426.250 .000 \\
\hline $\begin{array}{l}\text { Nilai Persediaan } \\
\text { Akhir }\end{array}$ & & & & & & 6.952 .659 .000 \\
\hline
\end{tabular}




\section{LAMPIRAN 2}

TABEL PERHITUNGAN NILAI PERSEDIAAN METODE FIFO

\begin{tabular}{|c|c|c|c|c|c|c|c|c|c|}
\hline & \multicolumn{3}{|c|}{ Pembelian } & \multicolumn{3}{|c|}{ Penjualan } & \multicolumn{3}{|c|}{ Saldo } \\
\hline Tanggal & Unit & Harga & Total & Unit & Harga & Total & Unit & Harga & Total \\
\hline Desember 2017 & & & & & & & 5.000 & 137.500 & 687.500 .000 \\
\hline \multirow[t]{5}{*}{ Januari 2018} & & & & & & & 5.000 & 137.500 & 687.500 .000 \\
\hline & 9.500 & 139.600 & 1.326 .200 .000 & & & & 9.500 & 139.600 & 1.326 .200 .000 \\
\hline & & & & 5.000 & 137.500 & 687.500 .000 & & & \\
\hline & & & & 6.000 & 139.600 & 837.600 .000 & & & \\
\hline & & & & & & & 3.500 & 139.600 & 488.600 .000 \\
\hline \multirow[t]{5}{*}{ Februari 2018} & & & & & & & 3.500 & 139.600 & 488.600 .000 \\
\hline & 10.500 & 146.080 & 1.533 .840 .000 & & & & 10.500 & 146.080 & 1.533 .840 .000 \\
\hline & & & & 3.500 & 139.600 & 488.600 .000 & & & \\
\hline & & & & 6.500 & 146.080 & 949.520 .000 & & & \\
\hline & & & & & & & 4.000 & 146.080 & 584.320 .000 \\
\hline \multirow[t]{4}{*}{$\begin{array}{l}\text { Maret - April } \\
2018\end{array}$} & & & & & & & 4.000 & 146.080 & 584.320 .000 \\
\hline & 12.500 & 160.151 & 2.001.887.500 & & & & 12.500 & 160.151 & 2.001 .887 .500 \\
\hline & & & & 4.000 & 146.080 & 584.320 .000 & & & \\
\hline & & & & 7.700 & 160.151 & 1.233 .162 .700 & & & \\
\hline
\end{tabular}


Annisa Rahmawati \& Achmad Daengs : Implementasi Metode FIFO Dalam Perhitungan Nilai Persediaan Pada Pt.X Distributor Makanan..........

\begin{tabular}{|c|c|c|c|c|c|c|c|c|c|}
\hline & & & & & & & 4.800 & 160.151 & 768.724 .800 \\
\hline \multirow[t]{5}{*}{ Mei 2018} & & & & & & & 4.800 & 160.151 & 768.724 .800 \\
\hline & 10.100 & 178.169 & 1.799 .506 .900 & & & & 10.100 & 178.169 & 1.799 .506 .900 \\
\hline & & & & 4.800 & 160.151 & 768.724 .800 & & & \\
\hline & & & & 6.300 & 178.169 & 1.122 .464 .700 & & & \\
\hline & & & & & & & 3.800 & 178.169 & 677.042 .200 \\
\hline \multirow[t]{5}{*}{ Juni 2018} & & & & & & & 3.800 & 178.169 & 677.042 .200 \\
\hline & 10.200 & 188.900 & 1.926 .780 .000 & & & & 10.200 & 188.900 & 1.926 .780 .000 \\
\hline & & & & 3.800 & 178.169 & 677.042 .200 & & & \\
\hline & & & & 7.100 & 188.900 & 1.341 .190 .000 & & & \\
\hline & & & & & & & 3.100 & 188.900 & 585.590 .000 \\
\hline \multirow[t]{5}{*}{$\begin{array}{l}\text { Juli - Agustus } \\
2018\end{array}$} & & & & & & & 3.100 & 188.900 & 585.590 .000 \\
\hline & 10.500 & 200.500 & 2.105.250.000 & & & & 10.500 & 200.500 & 2.105 .250 .000 \\
\hline & & & & 3.100 & 188.900 & 585.590 .000 & & & \\
\hline & & & & 6.400 & 200.500 & 1.283 .200 .000 & & & \\
\hline & & & & & & & 4.100 & 200.500 & 822.050 .000 \\
\hline \multirow[t]{2}{*}{ September 2018} & & & & & & & 4.100 & 200.500 & 822.050 .000 \\
\hline & 21.000 & 211.900 & 4.449 .900 .000 & & & & 21.000 & 211.900 & 4.449 .900 .000 \\
\hline
\end{tabular}




\begin{tabular}{|c|c|c|c|c|c|c|c|c|c|}
\hline & & & & 4.100 & 200.500 & 822.050 .000 & \multirow[b]{3}{*}{5.100} & \multirow[b]{3}{*}{211.900} & \multirow[b]{3}{*}{1.080 .690 .000} \\
\hline & & & & 15.900 & 211.900 & 3.369 .210 .000 & & & \\
\hline & & & & & & & & & \\
\hline \multirow[t]{5}{*}{ Oktober 2018} & & & & & & & 5.100 & 211.900 & 1.080 .690 .000 \\
\hline & 16.000 & 224.050 & 3.584 .800 .000 & & & & 16.000 & 224.050 & 3.584 .800 .000 \\
\hline & & & & 5.100 & 211.900 & 1.080 .690 .000 & & & \\
\hline & & & & 6.900 & 224.050 & 1.545 .945 .000 & & & \\
\hline & & & & & & & 9.100 & 224.050 & 2.038 .855 .000 \\
\hline \multirow[t]{5}{*}{ November 2018} & & & & & & & 9.100 & 224.050 & 2.038 .855 .000 \\
\hline & 19.000 & 236.893 & 4.500.967.000 & & & & 19.000 & 236.893 & 4.500.967.000 \\
\hline & & & & 9.100 & 224.050 & 2.038 .855 .000 & & & \\
\hline & & & & 1.900 & 236.893 & 450.096 .700 & & & \\
\hline & & & & & & & 17.100 & 236.893 & 4.050 .870 .300 \\
\hline \multirow[t]{4}{*}{ Desember 2018} & & & & & & & 17.100 & 236.893 & 4.050 .870 .300 \\
\hline & 31.150 & 250.900 & 7.815.535.000 & & & & 31.150 & 250.900 & 7.815.535.000 \\
\hline & & & & 17.100 & 236.893 & 4.050 .870 .300 & & & \\
\hline & & & & 1.700 & 250.900 & 426.530 .000 & & & \\
\hline Akhir & & & & & & & 29.450 & 250.900 & 7.389 .005 .000 \\
\hline
\end{tabular}


Annisa Rahmawati \& Achmad Daengs : Implementasi Metode FIFO Dalam Perhitungan Nilai Persediaan Pada Pt.X Distributor Makanan.......... 